\title{
Pollution Risk Reduction in Municipal Slaughterhouse Michoacán México by System Hazard Analysis and Critical Control Points (HACCP)
}

\author{
Juan Manuel Díaz-Maldonado, Juan Pablo Flores-Padilla, Mauricio Perea-Peña, Isaías de Jesús Díaz- \\ Maldonado, Encarnación Ernesto Bobadilla-Soto, and Guillermo Salas-Razo
}

\begin{abstract}
In this paper a system for reducing contamination risks in the methodology of analysis and critical control points (HACCP) was applied. The job gets done in a municipal slaughterhouse in the state of Michoacán, México, through the HACCP methodology and under the official Mexican standards (NOM) for its acronym in Spanish. This hard work 180 days, an analysis at the beginning and after applying the HACCP prerequisites were applied, the five preliminary tasks and the seven principles of HACCP is performed. The results show that the trail has 20 years of operating and investment not received with the application of HACCP pollution was reduced during the process but this is not enough and that the part of provider deficiencies found.
\end{abstract}

Index Terms-System contamination risk reduction, hazard analysis and critical control points, slaughterhouse.

\section{INTRODUCTION}

The food safety is the result of several factors, including compliance with legal requirements and implementation of quality assurance programs and based on a system of risk reduction pollution. In this regard it is noted that the technological advances in the food industry and safety are issues to be addressed along the food chain, since it can have constants appearances and microbiological hazards that may be foodborne [1]. Therefore, it is important to create a diagram that integrates research, food monitoring and epidemiological research in an effort to reduce foodborne diseases, so it is considered that the food safety of agricultural origin, aquaculture and fisheries are and will be a key issue for the public health care for all countries [2], without forgetting the concept of one health indicated by the International Organization for Animal health [3]. It is believed that foodborne illnesses as a result of microbial pathogens, bio-toxins and chemical contaminants pose serious threats to the health of millions of people [4]. In the past decades have been documented on all continents serious outbreaks of foodborne diseases, demonstrating its importance from the point of view of social and public health [5], [6]. The foodborne diseases can be generated from food or water contaminated with pathogens that affect consumer health [7] and possibly labor of manipulate is the principal factor [8]. In this context, governments in several countries, identified their trade different risks and hazards that can cause direct damage to health, for example, the

Manuscript received December 5, 2013; revised March 19, 2014

The authors are with the Universidad Michoacana de San Nicolás de Hidalgo. Michoacán, México (e-mail: gsalas55@hotmail.com).
Government Control Agency Argentina (2011) [9] states that to date have been identified more than 250 foodborne diseases, most as a result of infections caused by Salmonella ssp., Escherichia coli (Enterobacteriaceae), Campylobacter (Campylobacteraceae) and Listeria monocytogenes (Listeriaceae).

It has traditionally been considered the meat as vehicle for a significant proportion of human foodborne diseases. It has changed the spectrum of the meat-borne diseases, which are of importance to public health, together with the changes in the production and processing systems. The fact that the problem still has been well illustrated in recent years with surveillance studies in humans concerning meat-borne pathogens such as Escherichia coli O157: H7, Salmonella spp, Campylobacter spp. and Yersinia enterocolitica. Apart from the biological, chemical and physical hazards, dangers are emerging, for example, the agent of bovine spongiform encephalopathy (BSE). Also, consumers have expectations about the suitability issues that are not necessarily significant to human health [10].

In México is reported as the major etiological agent of food -borne diseases, Salmonella ssp., and Escherichia coli, likewise, the newsletters published epidemiological evidences the lack of implementation of good hygiene practices, including risk reduction activities of contamination [11].

All the above examples were identified thanks to systems and methods marked in several laws; however, the European community has created a system of rules that guarantee and reduce the potential danger when trading with countries around the world, for that reason, the codex represents a set of rules and regulations that should be reviewed prior to market with Europe and its member countries.

The Codex Alimentarius (2012) [10] established that the foodborne diseases, is a major concern due to growth in its occurrence. The incidence of these diseases is a direct indicator of the hygienic-sanitary quality of foods and has been shown that contamination of these can occur during processing or the use of contaminated raw materials. Control of foodborne diseases by health authorities and food processing plants, depends to some extent on the analytical method used for detection [7].

Given the history of food-borne diseases is important to mention that México has a regulatory framework, the regulatory framework is aligned to global health policy set by the OIE, WHO and FAO (One Health), prevailing generation systems to reduce pollution risks under the method of the Hazard Analysis and Critical Control Point (HACCP), this without impairing the Federal Animal Health 
Law, published on July 27, 2007 and the publication of its regulations, this document is the basis for development related to food production agricultural, aquaculture and fisheries activities origin.

In México, the health regulations of the tracks, is emphasized in the Federal Law on Animal Health (LFSA, acronym in Spanish) [12], which in the second chapter title II, art. 4 provides in general context, the system of Hazard Analysis and Critical Control Point (HACCP) this system is a risk of pollution reduction which is applied in primary production, in traces Federal Inspection Type (TIF) engaged in slaughtering and processing of goods of animal origin. This system allows identify and prevent hazards and risks of contamination biological, chemical or physical, which can affect the integrity of the goods of animal and / or public health.

There are also Mexican Official Standards, which help the reduction of risk food contamination. The food (ETA) borne illnesses can be generated from food or water which is contaminated by pathogenic microorganisms that affect the health of consumers. The higher incidence of infections is occasioned by Salmonella ssp., Escherichia coli Migula (Enterobacteriaceae), Campylobacter Sebald \& Veron (Campylobacteraceae) and Listeria monocytogenes, Murray (Listeriaceae) [7]. These illnesses not only has a significant impact in the health and welfare of people, but also has an economic consequences for individuals, families, communities, companies and countries, that imposes a considerable burden health care systems and reduced economic productivity [13].

The process of contamination of meat on trail begins with the killing, even in traces hygienic is possible cross contamination which occurs with hands and knives contaminated with feces. After sacrifice, the dressing process is theoretically a sterile process, but to develop a highly nutritious environment near water availability and potential of hydrogen $(\mathrm{pH})$ to neutrality replication of a large number of microorganisms are favored some pathogens [14].

Due to the lack of implementation of systems to reduce risks of contamination trails, surveillance system reported an increase in the number of cases in forborne illnesses, an increase in the incidence of disease by meat consumption, which has a low hygienic quality, having a negative impact on public health of the Mexican population. This is due to deficient sanitation process for obtaining meat [15].

Despite the intense nature of the application resource programs meat hygiene, evaluating their total profit is still limited by the lack of implementation of systems in the process of slaughter and sanitary hygienic handling of meat, related to public health. Therefore, it is considered that the application of the principles of risk management should gradually improve the situation, particularly in the area of sacrifice. In the present work, aims to develop and implement Hazard Analysis and Critical Control Point to reduce risk of contamination in municipal slaughterhouse of Michoacán state.

\section{MATERIAL AND METHODS}

The study was conducted in a municipal slaughterhouse in the state of Michoacán, México, located between the coordinates $17^{\circ} 55^{\prime}$ 'and $20^{\circ} 24^{\prime}$ north latitude, and coordinates $100^{\circ} 04^{\prime}$ and $103^{\circ} 44^{\prime}$ west longitude, which has over 20 years.

This study is qualitative, developed in 180 days under the methodology of HACCP, inspection is performed based on the NOM- 008- ZOO- 1994, through an assessment which consists of 16 points, which was applied in the beginning and the end, through observation, data were analyzed on a sheet of Microsoft Office Excel 2007 C , to express the data in percentage , according to the degree of compliance based on the assessment. As prerequisites Trail joined the process, the manual of good sanitation practices in trails were applied in the process of NOM -251- SSA1 -2004 and NOM-009ZOO-1994, which will talk about the meat health's process, applying each point in the process, as well as personnel. It began with pre-requisites, then this, the previous five points and seven HACCP principles were applied.

\section{RESUlTS AND DISCUSSION}

It was found that the trail has 60 employees, of which 540 cattle slaughtered per week on average, with the larger working days Monday and Thursday, these two days, people not reached all activities within their work schedule, so the quick hits no matter whether it is appropriate or inappropriate for the process.

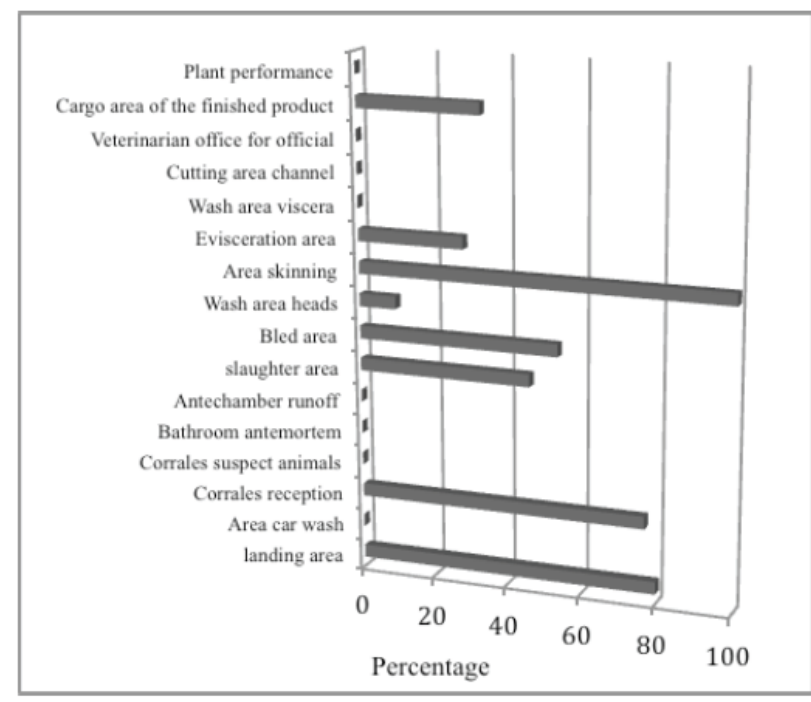

Fig. 1. The percentage of compliance areas of the slaughterhouse.

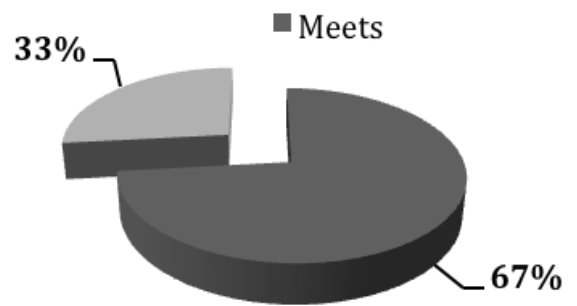

Fig. 2. Initial assessment based on the NOM-008-ZOO-1994.

In Fig. 1, the first evaluation with 16 components and the percentage of completion of each area show.

The first assessment Fig. 2, affects the poor infrastructure and lack of training in the health process meat, having a compliance of $33 \%$. The current state of the system was determined to assess this in the context of conditions and 
determine the areas of greatest attention the implementation of the HACCP.

In Fig. 3, is observed what can be improved the areas and thus percentage in the different areas, from last evaluation. Some areas went from 0 to $100 \%$ compliance, with respect to the first evaluation.

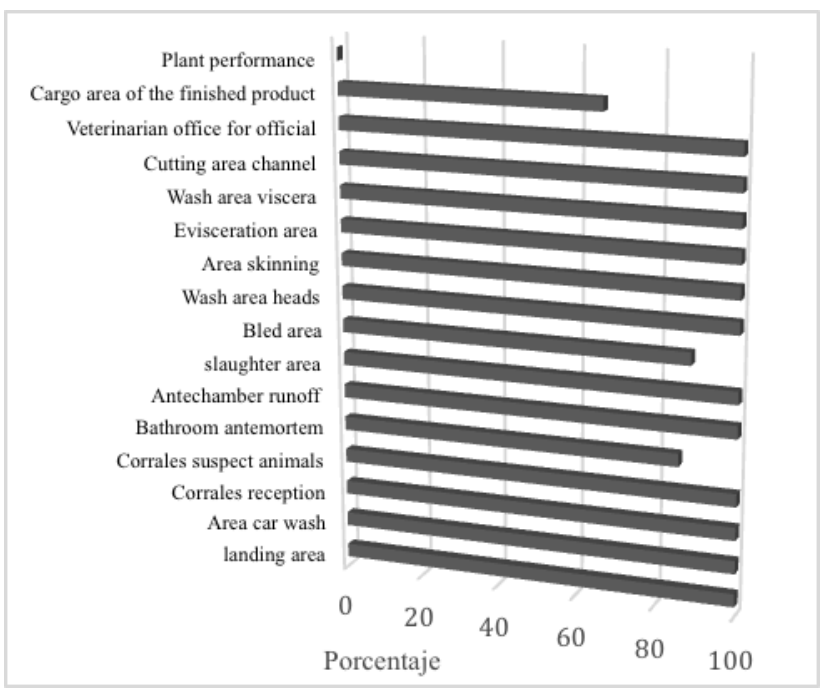

Fig. 3. Final evaluation for areas showing percentage of fulfillment in slaughterhouse.

An achievement rate of $88 \%$ is observed in the final evaluation Fig. 4, indication a degree of advance of $50 \%$.

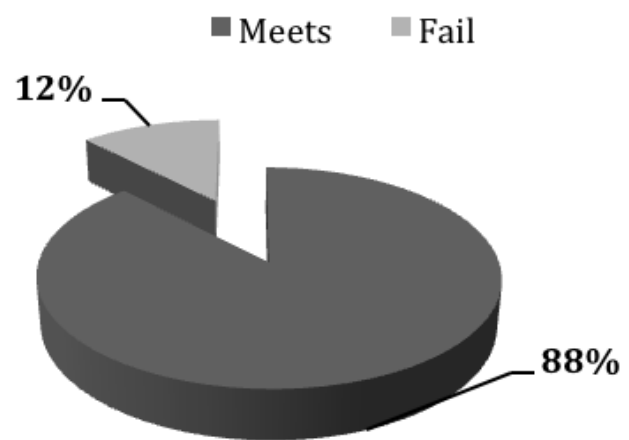

Fig. 4. The final evaluation based on the NOM-008-ZOO-1994.

It is established that the lack of investment and maintenance courses, basic sanitation activities are essential ways to meet the new provisions of the rules and laws, which are in application in México.

It should form the HACCP team with people with experience and specific knowledge about the product and the process, from the above, this is considered a multidisciplinary team because seeks to ensure food safety avoiding physical, chemical and microbiological. He suggests the help of external experts, with knowledge of the biological, chemical and physical hazards associated with the product and the process [16]. Forming the HACCP team found staff resistance, once they sensitize people to change, this is conformed of a labs workers, a specialist in SRRC, two zootecnista veterinarian determined the pathologies, a physician by the health secretary for determination of contaminants, which are external to the plant. The trained team understands the coordinator, person responsible for documentation, of the documents validation, responsible for the review process, a secretary, which were plant personnel which has knowledge of processes of this same.
Once formed the team, made a product description, in which the team found that the meat is animal muscle tissue, which is consumed as food, this man provides proteins. The ingredients that are used in this case are live animals and water, water is used when the animal take a shower and the carcass is washed to remove blood and bone sawdust, which can cause health damage if its contaminated, beef is red, contains fat, connective tissue, in the physical and chemical properties it was found that due to the protein content once exposed to the exterior has an accelerated rate of alteration due to moisture and $\mathrm{pH}$, the expected lifetime is one week, ways of storing the meat is in a refrigeration chamber to give the maturation process or if required by owner meat goes unrefrigerated property, in some cases distributed in vans without lids as the company distributed in a private vehicle.

In the list of intended use, it was found that the product is mainly sold in butchers who sell to final consumers are persons of all ages, in some cases delivered to restaurants, nursing homes, orphanages, hospitals and public sale of food in taco. In preparing the flow chart of the different processes dressing area, which are receiving the animal, desensitization, bled, gutted and skinning, head cleaning, gutting, washing of viscera, a division of the canal, and washing were found inspection. When showing site diagram, was found that they were not conducting inspections within the process by the veterinarian.

Once completed these requirements previous five HACCP we preceded to implementation of the seven principles is approaching, to develop hazard analysis in which physical, chemical and biological hazards were identified.

This activity consisted of identify potential hazards associated with the slaughter process at all stages [17], considering the probability of occurrence (risk) and severity. Using Qualitative Ranking table Backed by FAO, the Canadian agriculture and food institution and national service of fishery products from the United States of America. It was found that the principal dangers are: wood, stone, manure, bone, biological agents of zoonotic type (Tuberculosis, Brucella, Taenia, Ascaris), rumen fluid, intestinal fluid, lubricating machinery, metal fragments.

Having identified the hazard critical control points, control at this stage and it is applied to eliminate safety hazards of meat and reduce it to an acceptable level is determined [18]. Besides this point was developed through a decision tree which helped find the critical control points [10], [18]-[20]. When it was found that the main Critical Control Points are skinning and gutting.

By establishing critical limits, Table I, which are indicative to ensure that the CCP does not suffer deviations were found in the first samplings detours as animals with medication, hormonal implants, lesions of tuberculosis, especially animals from state of Jalisco México. The number of cases found covering the period of investigation.

For surveillance and monitoring of each critical control point formats which consist of noting deviations which are continually observed that in rainy weather skinning area, was contaminated up to $80 \%$ of the canals have been designed due to runoff from the skin to the flesh and skin of poor position to remove, in the evisceration area on 
Mondays and Thursdays are the days with the highest number of slaughtered the rupture of thin intestine, urinary bladder animals uterus and gall bladder was $75 \%$, because the manager that area did not perform adequate process, this monitoring process is continuous.

Within the corrective actions that were implemented was washing affected parties to prevent the contamination would spread, the removal of the affected parts of the canal and its seizure, in the case of finding disease or injury abscesses we proceed to remove of the channel and if needed are sent to the laboratory for diagnosis of disease and determine if it is safe to consume or not.

To establish verification procedures were under the guidelines of CODEX applying methods, procedures, tests and other evaluations, in addition to monitoring to determine compliance with the HACCP plan, in which the laboratory of applied NOM-194-SSA1-2004, NOM-034-SSA1-1993, these for the purpose of test the effectiveness HACCP.

With these activities the folder to check the SRRC marked in the law was created.

TABLE I: MAXIMUM PERMITTED LIMITS BASED ON THE NOM-034-SSA11993, NOM-194-SSA1-2004 AND NOM-031-ZOO-1995

\begin{tabular}{|c|c|c|c|}
\hline $\begin{array}{l}\text { NOM-034-SSA1- } \\
1993\end{array}$ & Pathogens & $\begin{array}{l}\text { Maximum } \\
\text { limits }\end{array}$ & Cases \\
\hline \multicolumn{4}{|l|}{ 6. Health provisions } \\
\hline $\begin{array}{l}\text { 6.3. Failure to submit } \\
\text { any of the following } \\
\text { abnormalities }\end{array}$ & $\begin{array}{l}\text { Smell, abnormal } \\
\text { color or flavor } \\
\text { Necrotic areas }\end{array}$ & Absent & 10 animals \\
\hline & Frostbite & & 5 animals \\
\hline \multicolumn{4}{|l|}{$\begin{array}{l}\text { 7. Sanitary } \\
\text { specifications }\end{array}$} \\
\hline 7.1. Physicochemical & $\mathrm{pH}$ & 6.5 a 6.8 & $\begin{array}{l}30 \text { animals } \\
\text { whit } 5.0\end{array}$ \\
\hline \multicolumn{4}{|l|}{$\begin{array}{l}\text { NOM-194-SSA1- } \\
2004 \\
\text { 6. Specifications }\end{array}$} \\
\hline \multirow[t]{6}{*}{ 6.10.1. Vermin } & Bladder worm & & 0 \\
\hline & $\begin{array}{l}\text { Cysticercus } \\
\text { bovis }\end{array}$ & Absent & 1 \\
\hline & $\begin{array}{l}\text { Cysticercus } \\
\text { cellulosae }\end{array}$ & & 0 \\
\hline & Trematodes & & $\begin{array}{l}\text { Fasciola } \\
\text { Hepática } \\
400 \text { in rain }\end{array}$ \\
\hline & Cestodes $y$ & & Ascaris 10 \\
\hline & nematodes & & Taeni 1000 \\
\hline 6.10 .3 & $\begin{array}{l}\text { Free of foreign } \\
\text { matter }\end{array}$ & Absent & $\begin{array}{l}200 \text { wire in } \\
\text { stomach }\end{array}$ \\
\hline 6.10.5 Pollutants & Clenbuterol & Absent & 2 cases \\
\hline $\begin{array}{l}\text { NOM-031-ZOO- } \\
1995\end{array}$ & Tuberculosis & & 200 cases \\
\hline
\end{tabular}

\section{CONCLUSION}

The slaughterhouse has more than 20 years in operation, and has lacked investment for modernization and updating based on health processes, Mexican Official Standards and public policy. It greatly reduced the contamination within the process, but despite this the HACCP plan was not effective because in the prerequisites section provider Failed to reliable providers, which is not allowed to generate safe meat.

\section{ACKNOWLEDGEMENTS}

The CONACYT by providing the scholarship for Master's studies at the Institute of Agricultural and Forestry
Research (IIAF) of UMSNH, México; to development of the research project.

The staff of the municipal slaughterhouse in Morelia City, state of Michoacán, México.

\section{REFERENCES}

[1] E. Pérez, P. Aguilar, R. Salvatella, A. Ribetto, and A. Castro, "Vigilancia de las Enfermedades Transmitidas por Alimentos (ETA's)," México, 2008.

[2] M. I. J. Díaz, Instrumentación HACCP en un sistema intensivo de producción porcina. Published in ler Congreso Internacional de Inocuidad Pecuaria, México, September 10-11, 2009.

[3] World Organization for Animal Health (OIE). Reunión internacional sobre las enfermedades emergentes y su vigilancia, Austria, February 15-18, 2013.

[4] Food and Agriculture Organization (FAO). (May 2012). Organización Mundial de la salud (OMS). World Organisation for Animal Health (OIE). [Online]. Available: http://apps.who.int/gb/ebwha/pdf_files/A62/A62_21-sp.pdf

[5] P. I. y col Álvarez, Análisis Económico de la Seguridad Alimentaria, Universidad de Oviedo, España, 2001.

[6] Food and Agriculture Organization (FAO), Garantía de la inocuidad y calidad de los alimentos. Directrices para el fortalecimiento de los sistemasnacionales de control de los alimentos, Estudio FAO Alimentación y Nutrición, Ed. FAO, pp. 93, Italy, 2004.

[7] F. T. González and H. R. A. Rojas, "Enfermedades transmitidas por alimentos y PCR: Prevención y Diagnóstico," Salud Pública, vol. 47, pp. 388-390, México, 2005.

[8] M. I. J. Díaz, "Calidad Microbiológica de la leche de cabra después de la implementación de las buenas prácticas de producción," XXIII Reunión Nacional de Microbiología, Higiene y Toxicología de los alimentos en el $8^{\circ}$. Congreso Internacional sobre Inocuidad de los Alimentos, México, November 9-11, 2006

[9] Agencia Gubernamental de Control (AGC), Enfermedades Transmitidas por Alimentos, Boletín Informativo, Argentina, 2011.

[10] FAO Buenas prácticas para la industria de la carne, Fundación Internacional Carrefour, Roma 2007.

[11] Sistema Único de Información para la Vigilancia Epidemiológica (SUAVE). (May 2012). Dirección General Adjunta de Epidemiología, México. Boletin epidemiológico. [Online]. Available: http://www.epidemiologia.salud.gob.mx/dgae/boletin/indice

[12] Ley Federal de Sanidad Animal (LFSA), Diario Oficial de la Federación, July 25, 2007, México.

[13] W. E. Keene, "Lessons from investigation of foodborne disease outbreaks," JAMA, vol. 281, no. 19, pp. 1845-1847, 2006.

[14] L. Hurtado-Salinas, "Prevalencia de contaminación microbiológica de la carne producida en el Frigorífico y Rastro de Morelia," S.A. de C.V. Master Thesis., INSP, México, 2010.

[15] Dirección General de Epidemiologia DGEPI. (May 2013). [Online]. Available: http://www.dgepi.salud.gob.mx/boletin/2010/sem33/index. htm

[16] K. E. Stevenson and B. J. Taylor, "HACCP. Un Enfoque Sistemático para la Inocuidad Alimentaria," Capítulos 12 Acciones correctivas principio 5: Establecer acciones correctivas, Washington D.C. $4^{\circ} \mathrm{edic}$ pp. 97-101. USA, 2008.

[17] A. Oroquieta and D. Gnes, "Implementación y Auditoria del Sistema de Análisis de Peligros y Puntos Críticos de Control (HACCP)," Agro Consultora Plus, Argentina, 2011.

[18] CODEX Hazard Analysis and Critical Control Point (HACCP) System and Guidelines for Its Application, Annex to the Recommended International Code of Practice General Principles of Food Hygiene, FAO/WHO Codex Alimentarius Commission, Italy, 2003.

[19] M. I. Díaz, “J. Sistema de Análisis de Peligros y Puntos Críticos de Control para Certificación de un Sistema intensivo de Producción Porcina," Master Thesis., UMSNH, México, 2011.

[20] FAO, La utilización de los principios del análisis de riesgos y de los puntos críticos de control en el control de alimentos, Canada, 1994.

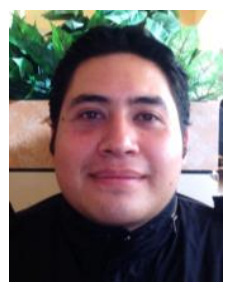

Juan M. Díaz-Maldonado was born in Michoacán, México. $\mathrm{He}$ is a veterinarian from Universidad Michoacana de San Nicolás de Hidalgo, México in 2011. He is degree student of master in animal production. 


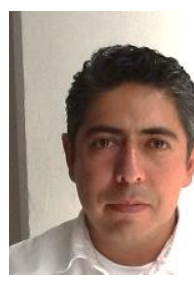

Juan P. Flores-Padilla was born in Michoacán, México. He received the master degree in technological development in animal production systems from Universidad Michoacana de San Nicolás de Hidalgo, México. He is a professor and researcher in animal production and rural development in the UMSNH. He published scientific papers in some Journals.

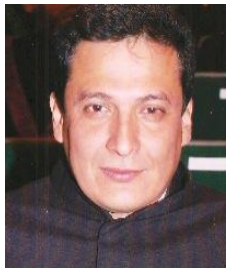

Mauricico Perea-Peña was born in Queretaro, México. He received the Ph.D. degree in agricultural sciences and natural resources from Universidad Autónoma del Estado de México, México in 2010. $\mathrm{He}$ is a professor and researcher in rural development in the UMSNH. He published almost 7 scientific papers in various Journals.

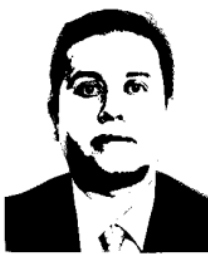

Isaías Díaz-Maldonado was born Veracruz, México. $\mathrm{He}$ received the master degree in technological development in animal production systems from Universidad Michoacana de San Nicolás de Hidalgo, México in 2012. He is a regional coordinator is campaign directorate animal health. He has published scientific and popular articles in Public Health, Health, Safety and Food Quality.

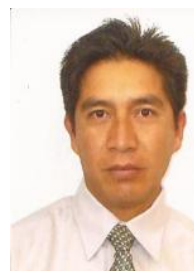

Encarnación E. Bobadilla-Soto was born in México, México. He received Ph.D. degree in agricultural sciences and natural resources from Universidad Autónoma del Estado de México, México in 2012. He is currently doing postdoctoral studies in Instituto de Investigaciones Agropecuarias y Forestales de la UMSNH. It has the recognition of the Nationa Research system of CONACYT (candidate SNI). He has published 12 scientific articles in various journals and 7 chapters in specialized books.

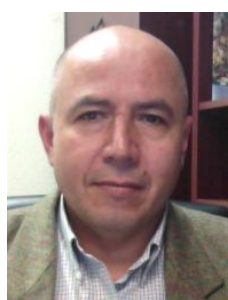

Guillermo Salas-Razo was born in Guanajuato, México, in 1967. He received the Ph.D. degree in biological sciences from Universidad Michoacana de San Nicolás de Hidalgo, México in 2008. He is a professor and researcher in animal production and rural development in the UMSNH. He is Director of the Institute of Agriculture and Forestry Research (IIAF) of UMSNH, Mexico; founding member of Red Bovinos AC., recognition of the National Research System of CONACYT-México (SNI I). He published almost 13 scientific papers in various Journals. 